\title{
Efficacy of Netraseka in Blepharospasm w.s.r to Kruchronmeelana
}

\author{
Case Report
}

\section{Sailaja Kalyadapu1* ${ }^{*}$ Praveen Kumar Madikonda², Johar B ${ }^{3}$}

1. P.G Scholar, 2. Associate Professor, 3. Head of the Department, P.G Department of Panchakarma, Dr. B.R.K.R. Govt. Ayurvedic Medical College, Hyderabad, Telangana. India.

\begin{abstract}
Blepharospasm is an act of involuntary blinking. In most of the cases, symptoms last for few days then disappear without any intervention. However in few cases, disease becomes chronic with symptoms of persistent blinking and the person will be able to open his eyes only with a great effort which could eventually lead to a functional blindness. Most of the times it is associated with ALO (Apraxia of lid opening). ALO is an inability to initiate voluntary eyelid opening following a period of eyelid closure. Manual lifting of the eyelid often resolves the problem and lid is able to stay open for a while thereafter. Botulinum toxin injections are the treatment of choice for both Blepharospasm and ALO, which is too expensive and at the same time have only a temporary improvement. In Ayurveda such condition is comparable with Kruchronmeelana which is postulated to be resultant of vata vitiation. Netrakalpana is the therapy of choice to treat above conditions. A single case study done at our department has shown significant improvement both in pain, blinking after the patient was subjected to Netraseka. Before Netraseka the same patient was treated with Aksitarpana which was done with triphala ghrita for seven days, but which hasn't produced much difference neither in pain nor in blinking. Netraseka was given with a specific kashaya for a period of 14 days following Tarpana therapy.
\end{abstract}

Key Words: Blepharospasm, Apraxia of lid opening, Kruchronmeelana, Aksitarpana, Netraseka.

\section{Introduction}

Blepharospasm is an involuntary recurrent spasm of both eyelids that occurs in elderly persons as an isolated phenomenon or with varying degrees of spasm of other facial muscles (1). It is a relatively common condition which, in its severe form, can be very disabling both in terms of vision and social functions. It is more common in Female with ratio of Female to Male 2:1 and it increases with age. It is a type of focal dystonia in which there is tonic spasm of the orbicularis oculi (2). It may be of 2 types.1.EssentialBlepharospasm, which occurs spontaneously and 2. Reflex Blepharospasm, which may be precipitated by sensory stimuli (3).

Essential blepharospasm is an uncommon but distressing idiopathic disorder which presents in the sixth decade and affects women more commonly than men by a 3:1 ratio. It is characterized by progressive involuntary spasm of the orbicularis oculi and upper facial muscles. In severe cases blepharospasm is disabling because it may temporarily render the patient functionally blind. Spasms may be precipitated by

\section{* Corresponding Author:}

\section{Sailaja K}

PG scholar

P.G Department of Panchakarma,

Dr. B.R.K.R. Govt. Ayurvedic Medical College,

Hyderabad, Telangana State, India

Email Id: vaidya.sailajanarasaiah@,gmail.com reading, driving, stress or bright light, and alleviated by talking, walking and relaxation.

\section{Treatment}

Prior to commencing treatment it is important to exclude reflex blepharospasm, most commonly due to ocular surface disease such as filamentary keratitis.

- Medical treatment with a great variety of drugs has been reported to ameliorate specific types of blepharospasm, but their efficacy is disappointing.

- Botulinum toxin injected along the upper and lower eyelid and eyebrow which gives temporary relief in most patients. By interference with acetyl choline release from nerve terminals it results in temporary paralysis of the injected muscles. Most patients require repeat injections every 3-4 months. By this treatment Side effects include lagophthalmos and ectropion or entropion, depending on the tone of the eyelids before the injection Accidental migration of the toxin into the orbit may result in ptosis and diplopia due to paralysis of the levator or extraocular muscles.

- Surgical treatment involves removal of the entire orbicularis, corrugator and procerus muscles. Such radical surgery is reserved for patients who cannot tolerate or are unresponsive to botulinum toxin (4).

Reflex Blepharospasm or Sensory Blepharospasm is commonly caused by bright light, corneal or eyelid irritation. Patients may complain of photophobia, a vague discomfort and a foreign body sensation. Treatment constitutes removal of the sensory stimulus (5). 
Blepharospasm has no direct difference in Ayurvedic classics. However, similar clinical manifestation can be observed in a disease called as Kruchronmeelana. It is mentioned by Vagbhata as one of the Vartma gataroga. In this Chalavata spreading through the siras (veins) of the eyelids, produce rigidity of the eyelid (inability to open) accompanied by pain after awakening from sleep. Associated symptoms are person feels as though the eye is filled with sand, difficulty to open the lid up, watering of eyes, feels happy by rubbing the eyes (6).

Vagbhata mentioned it as Aushadha sadyavyadhi (7). Snigdha nasya, Snigdhadhooma, snigdha Anjana with medicated Ghee which is prepared with Drakshakalka, Purana ghrita and Sugar (8).

\section{Aims and Objectives}

To check the efficacy of simplest and cost effective procedure Netraseka in Blepharospasm.

\section{Materials and Methods}

Patient was administered with Netraseka for a period of 14 days.

\section{Case History}

A female patient, aged 55 years, came to OPD of Panchakarma, Dr.B.R.K.R. Govt. Ayurvedic Hospital, Erragadda, Hyderabad on 26-06-2018 with chief complaints of Difficulty in opening of eyelids, Involuntary closing of eyelids and pain in facial muscles while opening of eyes associated with Heaviness of eyelids while opening and Headache occasionally for 2 years. She was diagnosed as a case of Blepharospasm. For 2 years she is taking Botax injections to eyelids. Patient was asymptomatic $3 \mathrm{yrs}$ back she developed frequent blinking of eyelids for 6 months then gradually developed difficulty in opening of eyelids.

\section{On Examination}

Opening of eyes with fingers, Slight shaking of Head while speaking.

\section{Clinical findings}

She was afebrile. The pulse rate was $74 /$ minute. Respiratory Rate was 16/minute and Blood Pressure was $110 / 70 \mathrm{mmHg}$. Systemic examination was within normal limits.

\section{Ocular examination}

On torch light examination, cornea was clear in both eyes, anterior chamber was normal in both eyes; pupils were of normal size and normal in reaction. On slit lamp examination, both eyes show mild nasal interpalpebral counjunctival staining with fluorescein. IOP in both eyes was $14.6 \mathrm{~mm} \mathrm{Hg}$.

\section{Visual examination}

In both eyes distant visual acuity was $6 / 12$. Best corrected visual acuity in both eyes was 6/6. Pinhole improvement in both eyes was $6 / 6$.

\section{Dashavidhapareeksha}

She was VatapittaPrakriti. Vikritiwas found to be Vatapitta. She was in Vrudhavasta. Her Satwa, Sara, Samhanana, Aharashakti, Vyayamashakti, Pramanaand Satmya were Madhyama.

Ashtavidhapareeksha: Her Nadi, Mutraand Shabda were Sadharana. Mala was Abadha. Jihwa was Anupalepa. Sparsha was Anushnaseetha. Akrithiwas Madhyama and Drik was Samanaya.

\section{Clinical diagnosis}

The diagnosis of blepharospasm is clinical and is made by careful history taking and physical exam.

\section{Laboratory test}

Laboratory tests have no utility in the diagnosis and workup of blepharospasm (9).

\section{Therapeutic Intervention}

Netraseka is one of the Netra kriyakalpa. The term Kriyakalpa comprises of 2 words kriya and kalpa where kriya means procedures used in treating the disease, kalpa means formulations.

Netraseka is the process in which medicinal liquids like taila, water, buttermilk, meat soup, decoction of the drugs, urine of various animals etc are poured on the closed eye in the form of thin stream from the height of 4 Angulas from the eye (10).

It is generally performed during day time. It can also be done during nights in emergency (11).

Table 1: Types of Netra kalpa in Samhitas

\begin{tabular}{|c|c|c|c|c|c|}
\hline Authors & $\begin{array}{l}\text { C a } \\
\text { Chi. } \\
26\end{array}$ & $\begin{array}{l}\text { Su. } \\
\text { Ut. } \\
18\end{array}$ & $\begin{array}{l}\text { A. S . } \\
\text { Su.32 }\end{array}$ & $\begin{array}{l}\text { Sa Ut. } \\
\text { kh. } 13\end{array}$ & $\begin{array}{l}B . P \\
M \text { a } \\
\text { kh. } 63\end{array}$ \\
\hline Total & 3 & 5 & 5 & 7 & 7 \\
\hline Achyotana & + & + & + & + & + \\
\hline Bidalaka & + & - & - & + & + \\
\hline Seka & - & + & + & + & + \\
\hline Anjana & + & + & + & + & + \\
\hline Tarpana & - & + & + & + & + \\
\hline Putapaka & - & + & + & + & + \\
\hline Pindi & - & - & - & + & + \\
\hline
\end{tabular}

Table 2: Types of Netraseka mentioned in Samhitas

\begin{tabular}{|c|c|c|c|c|}
\hline Types & Su.S & A.S & Sa.S & B.P \\
\hline Snehana & + & + & + & + \\
\hline Ropana & + & + & + & + \\
\hline Lekhana & + & + & + & + \\
\hline
\end{tabular}

Aksitarpana was done with Triphala ghritam to both the eyes for 100 Matrakalas (12) once daily for 7 days. After 7 days gap Netraseka with Triphala kashaya was done once daily for 2 cycles with the gap of 7 days. First cycle of Netraseka was done for 7 days, Second cycle for 14 days.

\section{Purvakarma}

- Proportion, quantity and method of preparation of Triphala Kwatha - Yavakoota (Coarse powder) of Triphala was mixed properly and 4 times water added (1part Dravya +4 part water) and boiled at low 
temperature till it became $3 / 4$ of total amount means $1 / 4$ reduced. The medicated decoction was filtered with the help of cotton so that there are no minute particulates in the decoction.

- Device/ Instruments for Seka: Jala neti dhara

- Preparation: Patient is made to lay in Supine position on Kriya Kalpa table. Eyes and whole face were cleaned with sterile cotton swab. MruduAbhayanga (mild massage) and Swedana (mild sudation) was done to the face to relax the patient and increase the vasodilation of local area.

\section{Pradhana Karma}

After Purva Karma patients was advised to close the eyes andNetrasekawith SukhoshnaTiphala kashayawas performed on the closed eyes from KaninikaSandhi as is indicated in the classical literature for 300 matrakalas (13) i.e 10 minutes from the height of four Angulas (fingers about 6-6.5 cm).

\section{Paschat Karma}

After the treatment, eyes were washed or cleaned with Luke warm water. Patient was advised to take rest and was advices not to see the bright objects and also not to take Kapha Vridhikara Ahara \& Vihara.

\section{Complications}

No complications of the procedure was noticed.

Table 3: Treatment Plan

\begin{tabular}{|l|l|l|l|}
$\begin{array}{l}\text { Treat m e n t } \\
\text { given }\end{array}$ & Drug name & Duration & $\begin{array}{l}\text { Ma t ra } \\
\text { Kala }\end{array}$ \\
\hline Aksitarpana & $\begin{array}{l}\text { Triph a la } \\
\text { ghritha }\end{array}$ & 7 days & 100 \\
\hline $\begin{array}{l}\text { Netraseka } \\
\text { (1st cycle) }\end{array}$ & $\begin{array}{l}\text { Triphala } \\
\text { kashayam }\end{array}$ & 7 days & 300 \\
\hline $\begin{array}{l}\text { Netraseka } \\
\text { (2nd cycle) }\end{array}$ & $\begin{array}{l}\text { Triphala } \\
\text { kashayam }\end{array}$ & 14 days & 300 \\
\hline
\end{tabular}

Figure 1: Aksitarpana

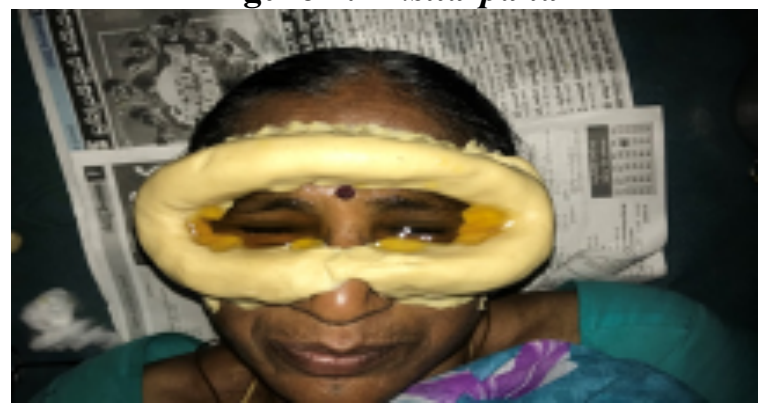

Figure 2: Netraseka

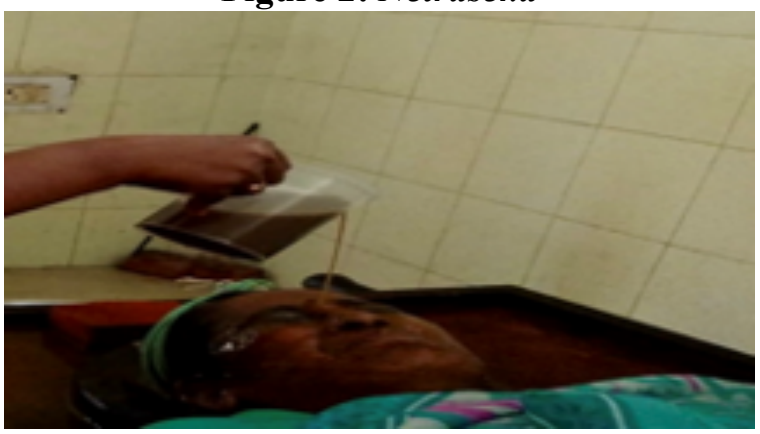

Table 4: Results

\begin{tabular}{l|l|l|l|} 
Parameters & $\begin{array}{l}\text { Before } \\
\text { Treatment }\end{array}$ & $\begin{array}{l}\text { After } \\
\text { Aksitarpana }\end{array}$ & $\begin{array}{l}\text { After } \\
\text { Netraseka }\end{array}$ \\
$\begin{array}{l}\text { Involuntary } \\
\text { Blinking }\end{array}$ & $\begin{array}{l}30 \text { times/ } \\
\text { day }\end{array}$ & $\begin{array}{l}\text { 20 times/ } \\
\text { day }\end{array}$ & $\begin{array}{l}\text { (Evening) } \\
\text { 1 time } \\
\text { (While } \\
\text { getting up } \\
\text { in the } \\
\text { Morning) }\end{array}$ \\
\hline $\begin{array}{l}\text { Duration of } \\
\text { Eye } \\
\text { Opening }\end{array}$ & $\begin{array}{l}45 \\
\text { Pain } \\
\text { intensity }\end{array}$ & Seconds & 35 Seconds \\
\hline
\end{tabular}

Figure 3: Opening of the Eyes before treatment

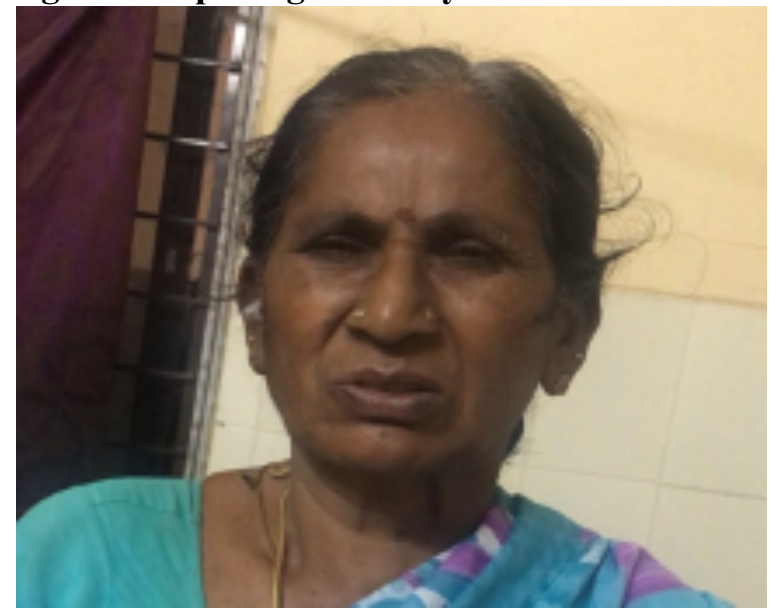

Figure 4: Opening of the Eyes after treatment

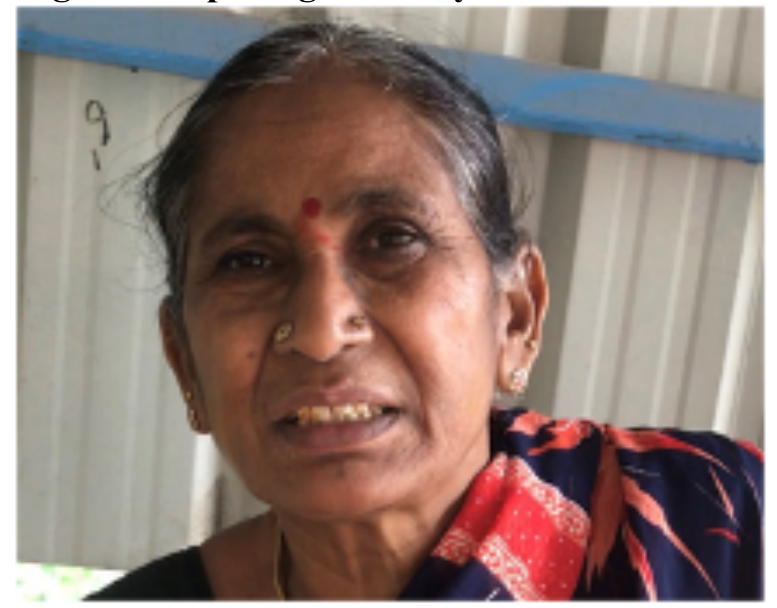

\section{Discussion}

Initially patient was treated with Aksitarpana with Triphala ghritha for 7 days as the disease condition was considered as Vata predominance, but the improvement was insignificant and even the pain did not reduce. The disease first started with the clinical findings such as involuntary blinking followed by difficulty in opening of eyelids. These findings showed resemblance with Essential Blepharospasm which is characterised by spasm of orbicularis oculi and upper facial muscles. As patient had main complaints of difficulty in opening eyes, because of the spasm, we 
tried Lekhana Netraseka (which is indicated for kaphaja Netra rogas) with warm Triphala kashaya. First, Netraseka was done for 7 days and we noticed significant improvement in her symptoms. We have given 7 days gap to check whether the improvement will last or not. But there is no change in improvement. Then again Netraseka was performed with warm Triphala kashaya for 14 days. There was marked improvement in her symptoms.

According to Dosha, in Alpa Bala disease Ashchyotana is helpful and in Balawan disease Seka is best (14). According to Chakradatta Seka, Sweda, Pralepa, Tikthaanna, Langhana are indicated in Amaavastha of Netra rogas and Seka will remove Netra dosas by Pachana karma (15).

As the disease Blepharospasm is chronic and sometimes becomes more painful that's the reason Seka Karma was chosen for the study. Seka can improve the eyelids disorders due to its deep penetrating properties. The thickness and integrity of stratum corneumis an important factor determining the transdermal drug absorption. Thicker skin is a greater barrier to passage of the drug. The skin of eyelid is the thinnest in the body and it measures approximately $0.05 \mathrm{~cm}$. The dermis is composed of rich network of elastic fibers, blood vessels, lymphatic's and nerves (16). Penetration of a drug occurs through the stratum corneum, underlying viable epidermis, dermis, and then finally into the circulatory and lymphatic system. Sukhosna Kwatha (mild hot fomentation) removes debris, bacteria, bacterial toxins, scales and crusts from the minute folds of the skin and thereby helps to maintain the lid hygiene. Netraseka improves the vascular supply by vasodilation and helps in faster and effective absorption.

\section{Mode of Action of Netraseka}

Triphala has the qualities of kaphapittaghna, Chaksusya, Sara, Deepana (17).

In this Netraseka procedure by the virya, karma and prabhava of drugs acts when comes in to contact with the skin of the eylids. By the qualities of the drugs, Pachana and Samana of netradosa can be attained. This help to break down the Samprapti - pathogenesis of the disease.

\section{Conclusion}

Netraseka appears to be more effective therapy for Blepharospasm when compared to Aksitarpana as frequency of blinking episodes and pain intensity reduced and duration of opening eyes has been observed to be decreased after the Netraseka therapy. The patient who couldn't open her eyes without the support of the fingers could do it with a minimal effort after the therapy.

\section{References}

1. Harrison's principles of Internal medicine, Fauci, Braunwald, Kasper, Haurer, Lango, Jameson, Loscalzo; 17th Edition: 2586p

2. Oxford handbook of Ophthalmology, AlastairK.O.Dennistan Philip I. Murray, Indian Edition; $564 p$

3. Parsons Diseases of the Eye, Editors Ramanjitsihota, RadhikaTandon, 20th Edition; 427p

4. Clinical Ophthalmology, A Systematic Approach by Jack J. Kanski, 5th Edition; 654-655p

5. Parsons Diseases of the Eye, Editors Ramanjitsihota, RadhikaTandon, 20th Edition; 428p

6. Astanga Hrdayam, Translated by Prof. K.R.Srikantha Murthy , Chaukhambakrishnadas Academy, Varanasi ; Uttarasthana, chapter $8^{\text {th }}$, 3-4 sloka, 74p

7. The ShalakyaTantra, Diseases of Eye, Head,and E.N.T. Dr. DingariLakshmana Chary ; Chapter 12, 98p 8. Astanga Hrdayam, Translated by Prof. K.R.Srikantha Murthy, Chaukhambakrishnadas Academy, Varanasi; Uttarasthana, chapter 9th, $1^{\text {st }}$ sloka, $80 \mathrm{p}$

9. https://eyewiki.aao.orgo/Blepharospasm

10. Sarangadhara Samhita of Sarangadharacarya, Translated by Dr. P. Himasagara Chandra murthy ,ChaukhambaSanskrit series office, Varanasi ; Uttarakhanda, chapter $13^{\text {th }}, 2^{\text {nd }}$ sloka, $399 \mathrm{p}$

11. Sarangadhara Samhita of Sarangadharacarya,Translated by Dr. P. Himasagara Chandra murthy, Chaukhamba Sanskrit series office, Varanasi ; Uttarakhanda , chapter 13th ,5th sloka, 399p 12. Principles of Ayurved, Astanga hrdaya, Vagbhata with English translation and commentary, T.Sreekumar, MD (Ayu). PhD; Sutrasthan, $2^{\text {nd }}$ volume, Chapter 24th, $7^{\text {th }}$ sloka, $166 \mathrm{p}$

13. Sarangadhara Samhita of Sarangadharacarya,Translated by Dr. P. Himasagara Chandra murthy, Chaukhamba Sanskrit series office, Varanasi ;Uttarakhanda, chapter $13^{\text {th }}, 4^{\text {th }}$ sloka, $399 \mathrm{p}$

14.Illustrated Susrutha samhitha, Translator Srikanthamurthy, Chaukhambhaorientalia, Varanasi, Reprint 2017; Uttaratantra, Chapter 18th, 44 sloka , $91 \mathrm{p}$

15. Cakradatta (Sanskrit text with English Translation) - Edited and Translated by Priyavratsharma, Chaukhambha publisher, Varanasi, Edition 2007; Chapter $64^{\text {th }}, 4^{\text {th }}$ Sloka, 482p

16. SaileshKonda, Susan R. Meier-Davis, Brenda Cayme, JutaroShudo, age related percutaneous penetration Part 1-Skin factors. Available from: http:// www.ncbi.nlm.nih.gov/pubmed/

17. Bhavaprakasha of Bhavamisra, commentary by Dr. BulusuSitaram, Foreword by Prof.K.C. Chunekar, Chaukhambhaorientalia, Varanasi, Reprint Edition 2018; Purvakhanda, chapter $6^{\text {th }}$, sloka 43, 136p. 